\section{IJ§ER}

ISSN: 2149-5939
International Journal of Social Sciences and Education Research

Online, http://dergipark.gov.tr/ijsser

Volume: 3(3), 2017

\title{
Avrupa İnsan Hakları Mahkemesi kararlarında basın özgürlügünü sınırlama nedeni olarak genel ahlak ${ }^{1}$
}

\author{
Morality as the limitation of press freedom in the decisions of the European Court of \\ Human Rights
}

\section{Z. Burcu Şahin ${ }^{2}$}

Received Date: 02 / 02 / 2017

Accepted Date: 03 / 06 / 2017

$\ddot{\boldsymbol{O}} z$

Ifade özgürlüğ̈̈nün en etkin kullanım araçlardan biri olan basın, çoğulcu demokratik rejimlerde, dördüncü kuvvet olarak yer alması nedeniyle tartışmasız bir öneme sahiptir. Basın, meşruiyetini kendisini demokratik rejimin bir parçası olarak gören bu görüşten alırken, ayn şekilde devlet de meşruiyetini ve güvenilirliğini basının denetim gücüyle sağlamakta; belgelemektedir. Sorumluluklar çerçevesinde kullanılabilecek bu özgürlüğ̈̈n, her özgürlük gibi sinırlandırılması kaçınılmazdır. Söz konusu alanda uluslararası bir yargı organı olan AIHHM, özellikle genel ahlak ve dini değerler gibi toplumların tarihi miras, kültürel gelenek ve görenekleriyle șekillenen hususlarda sözleșmeci devletlere nispeten genis bir takdir marjı bırakmaktadır Ancak bu takdir marjı da sınırsız değildir. Nitekim AÏHM diğer meşru sınırlama nedenlerinde olduğu gibi genel ahlak konusunda da çeşitli kriterler geliştirmiş olup dava konusu olayı söz konusu kriterler ışı̆̆ında ayrıntılı bir değerlendirmeye tabi tutmaktadir.

Anahtar sözcükkler: Basin, Ifade özgürlüğ̈̈, AIHM, Etik, Basin özgürlü̆̈̈̈

\begin{abstract}
Press, one of the most effective use tool of the freedom for expression, has an unarguable importance because of its place in pluralistic democratic regime as fourth force. As press takes its legality from this view which sees itself as a part of democratic regime, similarly the government ensures and certify its legality and security with the media's supervision power. This right that can be used within responsibilities is limited by certain reasons as all other freedoms. Although these limits range in different communities, the verdicts of European Court of Human Rigts show the increasingly tend to restrict the scope of the article in democratic countries. The ECHR, which is an international jurisdiction in the field, leaves a relatively broad margin of appreciation to contracting states, particularly in matters shaped by the heritage, cultural traditions and customs of societies, such as general morality and religious values, and adapts to the decisions of local authorities. As a matter of fact, the Court has developed various criteria for general morality as well as for the reasons of other legitimate restrictions and subject the case to a detailed assessment of the criteria.
\end{abstract}

Keywords: Press, Freedom of speech, ECHR, Ethics, Freedom of press

\section{Giriș}

Birden fazla kişinin varlığını ve etkileşimini gerektiren iletişimin beraberinde çeşitli hak, özgürlük ve sorumlulukları getirmesi kaçınılmazdır. İletişimin tabii gelişim seyri içinde, gerek iletişimin seyri ve içeriğinden gerekse kullanılan iletişim araçlarından hareketle birçok özgürlük ve hak kavramı ortaya çıkmıştır. Bu özgürlük ve hak kavramları günümüzde de çeşitlenmeye ve artmaya devam etmektedir. Basın özgürlügü ise basının iktidarı denetleme ve halkı bilgilendirmeyi içeren siyasi misyonu ile bu özgürlükler arasında önemli bir yere sahiptir.

1 “Türkiye'de Basın Özgürlüğü ve 2003 Yılı Sonrası Uygulamalar” başlıklı doktora tezinden derlenmiştir.

${ }^{2}$ Yrd. Doç. Dr., İstanbul Yeni Yüzyıl Üniversitesi, zeynepburcu.vardal@ yeniyuzyil.edu.tr 
Şahin, Z.B. (2017). Avrupa İnsan Hakları Mahkemesi kararlarında basın özgürlüğünü sınırlama nedeni olarak genel ahlak. International Journal of Social Sciences and Education Research, 945-956.

Basın özgürlüğü kavramı, içerdiği haklar ve sınırlamalar itibariyle birçok uluslararası belge ve Anayasa'da benzer tanımlamalara sahip olsa da çoğulcu demokrasiyle idare edilen her ülkede, değişen demokrasi algısı ve ekonomik-kültürel gelişmişlik düzeyi ile birlikte farklı uygulamalara olanak vermektedir. Bununla birlikte, basın özgürlüğünün diğer özgürlüklerle çatışan değerleri içinde barındırması da hukuki olarak zor bir zeminde yer almasına ve söz konusu çatışmanın sentezinin her toplumda farklı şekilde ortaya çıkmasına imkân vermektedir.

Basın özgürlüğü tanımlanması zor bir kavramdır. Bu nedenle birçok uluslararası belgede tanımlamalardan kaçınılmış; bunun yerine içerdiği haklar ve sınırları belirlenmek suretiyle kavramın açıklanması yoluna gidilmiştir. Nitekim iç hukukumuzda da bağlayıcı unsur taşıan Avrupa İnsan Hakları Sözleşmesi ve Avrupa İnsan Hakları Mahkemesi kararlarında da tercih edilen yöntem budur. Bununla birlikte, bu çalışmada, basın özgürlüğünün içerdiği haklar ve sınırlamalarının Avrupa İnsan Hakları Mahkemesi kararları çerçevesinde incelenmesindeki amaç, teorik düzeydeki bir incelemeden çok, Mahkeme'nin ifade ve basın özgürlüğünün sınırları konusundaki içtihatlarının incelenmesi suretiyle ülkemizdeki uygulamalara örnek teşkil edebilecek alternatifleri bulmak ve sunmaktır.

\section{Avrupa İnsan Hakları Sözleşmesi ve Avrupa İnsan Hakları Mahkemesi}

Avrupa Konseyi, 1949 yılında Avrupa çapında kurulmuş hükümetler arası bir kuruluştur. Amacı insan hakları, demokrasi ve hukukun üstünlüğünü savunmak olan kuruluş, bu anlamda ilk çalışmasını 4 Kasım 1950'de Roma'da imzalanan ve 10 devletin onaylamasından sonra 3 Kasım 1953’te yürürlüğe giren “İnsan Haklarını ve Ana Özgürlüklerini Korumaya İlişkin Sözleşme" "yle gerçekleştirmiştir. Türkiye, bu sözleşmeye, 10 Mart 1954'te katılmış; 28 Ocak 1987 'de ise Avrupa Konseyi'nin yargı organı olarak, AİHS ve ek protokolleriyle güvence altına alınmış, temel hak ve özgürlüklerin ihlali durumunda başvurulabilecek bir yargı mercii olan Avrupa İnsan Hakları Mahkemesi'ne bireysel başvuru yolunu açmıştır.

AİHS'nin ifade özgürlüğünü tanımlayan 10. maddesi, temelini 10 Aralık 1948'de yayımlanan İnsan Hakları Evrensel Bildirgesi'nin 19. maddesinden almakta ve söz konusu maddenin Sözleşme'nin en temel, en önemli hükümlerinden birini içerdiği genelde kabul görmektedir.

"Herkes ifade özgürlüğü hakkına sahiptir. Bu hak, kamu makamları tarafından müdahale olmaksızın ve ulusal sınırlar dikkate alınmaksızın, görüşlere sahip olma ve bilgi ve düşünceleri edinme ve bunları yayma özgürlügünü içerecektir. Bu madde, devletlerin, radyo, televizyon ya da sinema işletmeciliğinin izne/ruhsata bağlanması isteminde bulunmalarını engellemeyecektir."

Söz konusu madde ve Sözleşme, iç hukukumuz açısından da bağlayıcıdır. Nitekim 07.05.2004 tarihli ve 5170 sayılı “Türkiye Cumhuriyeti Anayasası'nın Bazı Maddelerinin Değiştirilmesi Hakkında Kanun”un 7. maddesiyle 1982 Anayasası'nın 90. maddesinin son fıkrasındaki, "Usulüne göre yürürlüğe konulmuş milletlerarası antlaşmalar kanun hükmündedir. Bunlar hakkında Anayasa'ya aykırılık iddiası ile Anayasa Mahkemesi'ne başvurulamaz.” fıkrasına aşağıdaki cümle eklenmiştir:

"Usulüne göre yürürlüğe konulmuş temel hak ve özgürlüklere ilişkin milletlerarası antlaşmalarla kanunların aynı konuda farklı hükümler içermesi nedeniyle çıkabilecek uyuşmazlıklarda milletlerarası antlaşma hükümleri esas alınır."

Avrupa İnsan Hakları Mahkemesi (AİHM), 1959 yılında, uluslararası bir teşkilat olan Avrupa Konseyi'ne bağlı olarak kurulmuş uluslararası bir mahkemedir. Mahkeme, Avrupa İnsan 
Şahin, Z.B. (2017). Morality as the limitation of press freedom in the decisions of the European Court of Human Rights. International Journal of Social Sciences and Education Research, 945-956.

Hakları Sözleşmesi ve ek protokolleriyle güvence altına alınmış olan temel hakların çiğnenmesi durumunda bireylerin, birey gruplarının, tüzel kişiliklerin ve diğer devletlerin, belirli usul kurallar dâhilinde başvurabileceği bir yargı merciidir. Türkiye de Avrupa Konseyi üyesi diğer 46 ülke ile birlikte AİHM'nin yetkisini tanımaktadır. Bununla birlikte 2004 yılında Anayasa'nın 90. maddesinde yapılan değişiklikle, temel hak ve özgürlükleri içeren başlıklar söz konusu olduğunda kanunların aynı konuda farklı hükümler içermesi durumunda uluslararası anlaşma hükümlerinin esas alınacağı da hükme bağlanmıştır.

\section{Basın özgürlüğü ve basın özgürlüğünün meşru sınırlama nedenleri}

Basın özgürlüğü, en genel sözlük anlamıyla "Görüş ve düşünceleri basın ve yayın yoluyla açıklayabilme ve yayabilme hakkı" olarak tanımlanmaktadır. (Çevrimiçi http://www.tdk.gov.tr/index.php?option=com_gts\&arama=gts\&guid=TDK.GTS.5352cb1639c8 97.18373597, 01.01.2013).

Basın, "toplum içinde düzenli olarak yayımlanan (veya halkın hizmetine verilen) haber veya bilgi öğelerinin (unsurlarının), düşünce veya kanıların biçim ve koşulların tümüdür.” (Danışman, 1982:1) Bununla birlikte, basın özgürlüğü denilince sadece gazetecilerin yararlanacağı bir özgürlükten bahsedilemez. Hasan Refik Ertuğ, bu unsuru göz önünde bulundurarak basın özgürlüğünü; "Haberleri, fikirleri ve bunların yorumlarını serbestçe toplamak, vasıtalı ve vasıtasız çoğaltmak ve umuma yaymak hususunda vatandaşlara (hatta bütün insanlara) tanınan hak" şeklinde tanımlamıştır. (Ertuğ, 2003:141) Türk Dil Kurumu'nun sözlüğünde, basın özgürlüğü kavramının iki karşılığı vardır; bunlardan ilki "görüş ve düşünceleri basın ve yayın yoluyla açıklayabilme ve yayabilme hakkı", diğeri ise "basının herkese açık olması ve herkesin basın işleriyle uğraşabilmesi özgürlüğü” dür. (Çevrimiçi http://www.tdk.gov.tr/index.php?option=com_ bilimsanat\&arama=kelime\&guid=TDK.GTS.5352cbbc34bb19.04453211, 24.12.2013).

Basın, düşünceyi açıklamak açısından bir kitle iletişim aracı olduğuna göre, basın özgürlüğü de "düşünce açıklamak özgürlüğü” kapsamında değerlendirilmeli; (Özek, 1999:223) ancak bu özgürlüklerin yapısal farklılıkları da göz önünde bulundurulmalıdır. Nitekim düşünceyi açıklama özgürlüğü kapsamında yer almayan hususlar da dikkate alınarak hazırlanan Basın Kanunu, düşüncenin açıklanma aracı olarak "basın" faaliyetinin hukuksal düzenini oluşturmaktadır. Basın, düşünceyi açıklama aracı olarak önemli bir kitle iletişim aracıdır. Basın özgürlüğü denilirken de ifade edilen, düşüncenin söz konusu iletişim aracı ile kitlelere ulaştırılma özgürlüğ̈̈dür. Televizyon, radyo ve internet gibi daha kısa bir geçmişe sahip olan kitle iletişim araçları ise yapısal ve işlevsel farklılıkları nedeniyle basından ayrı tutularak farklı düzenlemelere tabi tutulmuștur.

"Kişinin sahip olduğu düşünceyi yayma ve açıklama özgürlüğü, yazının ve matbaanın icadı ile yepyeni bir araç kazanmıştır." (Salihpaşaoğlu, 2007:14) Düşünceyi açıklama özgürlüğü kapsamında değerlendirilen basın özgürlüğünün yapısal farklılıklarının başında ise bir işletme bünyesinde gerçekleşebilmesi gelmektedir. Bu noktada, düşünceyi açıklama özgürlüğü kapsamında herhangi bir engel teşkil etmeyecek hususlar, basın özgürlügünü engelleyebilmektedir.

“Bu engeller basın özgürlüğünün kullanılmasını fiilen imkânsız hale getirebilirler. Basımevi kurmanın izin alma ya da mali teminat yatırma şartına bağlanması, yayımlanacak eserler için ön denetim getirilmesi buna örnek olarak verilebilir.” (Salihpaşaoğlu, 2007:14) 
Şahin, Z.B. (2017). Avrupa İnsan Hakları Mahkemesi kararlarında basın özgürlüğünü sınırlama nedeni olarak genel ahlak. International Journal of Social Sciences and Education Research, 945-956.

Özellikle demokratik rejimlerde basının önemi tartışılmazdır. Batı'da demokratikleşme sürecinin başlangıcı kabul edebileceğimiz 17. yüzyıldan beri basın, Dördüncü Kuvvet olarak görülmekte ve gerek teorik çalışmalarda gerekse pratikte basının önemi, basın özgürlüğü ve basın özgürlüğ̈̈nün sınırları, basının hak ve sorumlulukları üzerine çeşitli tartışmalar ortaya konmaktadır.

Temel hak ve özgürlükler kanuni metinlerde yer almaya başladığı andan itibaren sınırlarının nerede başlayıp nerede biteceği de ayrı bir tartışma olarak ortaya çıkmıştır. Bir başka deyişle, bu noktada, "Özgürlükler sınırsız mıdır?" sorusu karşımıza çıkmaktadır.

Klasik liberal doktrin de dâhil olmak üzere neredeyse bütün düşünce sistemleri, temel hak ve özgürlüklerin sınırlandırılması gerektiği üzerine fikir birliğindedirler. (Baykan, 2011: 69) Nitekim sadece genel prensipleri ilan edilen, ancak içeriği ve sınırları belirtilmeyen özgürlüklerin hukuksal anlamda bir geçerliği yoktur. Sınırları çizilmeyen bir özgürlük anlayışı, toplum halinde yaşamanın temel prensipleriyle uyum sağlayamamakta ve kısa zamanda anarşiye neden olabilmektedir.

1789 İnsan Hakları Beyannamesi’nde kişi hak ve özgürlükleri hususunda; “Hürriyet başkasına zarar vermeyen her şeyi yapabilmektir. Böylece her insanın doğal haklarını kullanması, toplumun diğer üyelerinin de aynı haklardan yararlanmasını sağlayan sınırlarla çevrilmiştir. Bu sınırlar ancak kanunla konur." (Mad. 4), "Kanunun, sadece toplum için zararlı eylemleri yasaklamaya hakkı vardır." (Mad.5) denmektedir. Günümüzde de kişisel hak ve özgürlüklerin sınırlandırılmasına bakıldığında, esas alınan genel prensibin bu ilkelerle uyuştuğunu söylemek mümkündür. Buna göre, kişilerin sahip olduğu temel hak ve özgürlüklerin kanuni teminat altına alınmakla beraber, sınırsız olamayacağı belirtilmiştir.

Günümüzde basın özgürlüğünün sınırları hususunda birçok Anayasa'nın AİHS'nin 10. maddesinde sıralanan sınırlamaları benimsediği görülmektedir. AİHS'nin 10 maddesi, temelini 10 Aralık 1948'de yayımlanan İnsan Hakları Evrensel Bildirgesi'nin 19. maddesinden almakta ve Sözleşme'nin en temel ve en önemli hükümlerinden birini içerdiği, genelde kabul görmektedir. (Bıçak, 2001:56)

Sözleşme'nin 10. maddesinde; "Herkes görüşlerini açıklama ve anlatım özgürlüğüne sahiptir. Bu hak, kanaat özgürlüğünü, kamu otoritelerinin müdahalesi ve ülke sınırları söz konusu olmaksızın haber veya fikir alma ve verme özgürlüğünü de içerir. Bu madde, devletlerin radyo, televizyon ve sinema işletmelerini bir izin rejimine bağlı tutmalarına engel değildir." denmektedir. Maddenin devamında ise bu özgürlüklerin kullanılması görev ve sorumluluklar yükleyen özgürlükler olduğu belirtilmiş ve kanunla öngörülen bazı formalitelere, şartlara, sınırlamalara ve yaptırımlara bağlanılabileceği belirtilmiştir.

$\mathrm{Bu}$ sınırlamalar şu şekilde sıralanmıştır;

-Zorunlu tedbirler niteliğinde olarak, ulusal güvenliğin, toprak bütünlüğünün veya kamu güvenliğinin korunması,

- Asayişsizliğin veya suç işlenmesinin önlenmesi,

- Genel sağlığın ve ahlakın, başkalarının ün ve haklarının korunması,

- Gizli kalması gereken haberlerin yayılmasına engel olunması veya yarg1 gücünün otorite ve tarafsızlı̆̆ının sağlanması. 
Şahin, Z.B. (2017). Morality as the limitation of press freedom in the decisions of the European Court of Human Rights. International Journal of Social Sciences and Education Research, 945-956.

Yine aynı Sözleşme'nin 17. maddesinde; "Bu sözleşme hükümlerinden hiçbiri, bir devlete, topluluğa veya kişiye, sözleşmede tanınan hak ve özgürlüklerin yok edilmesine veya burada öngörüldüğünden daha geniş ölçüde sınırlandırmaya yönelik bir faaliyete girişme ya da eylemde bulunma hakkını verir anlamında yorumlanamaz.” denmektedir. Söz konusu madde, bize özgürlükleri sınırlamanın da sınırı olacağını işaret etmektedir. Bir diğer önemli husus da bu sınırlamaların hangi ölçüde meşru ve yerinde kabul edilebileceğidir.

Günümüzde basın özgürlüğünü de kapsayan ifade özgürlüğüne ilişkin kısıtlamaların özellikle gelişmiş Batı ülkelerinde mümkün olduğunca daraltıldığı görülmektedir.

Oya Araslı’ya göre; günümüzde düşünceyi yayma özgürlüğü, demokratik düzenin yerleşmesiyle bu düzene aykırı düşüncelerin de ifade edilebileceği şekilde genişletilmektedir. Nitekim bazı ülkeler, tarihlerinde bir noktaya gelene kadar demokrasiye aykırı düşüncelerin, demokratik düzen tarafından korunamayacağını söylemiş, demokratik düzen geliştiği zaman ise herhangi bir sınırlamaya tabi tutulmadan bu düşüncelerin alabildiğince telaffuz edilmesine imkân vermişlerdir. (Araslı, 1995:19) Bu görüş de bize demokrasi ile basın özgürlüğü arasındaki sıkı ilişsiyi göstermektedir. Öyle ki demokrasi, vardığı son noktada, ona aykırı ifadelerin dahi serbestçe ifadesine izin vermektedir. Demokrasinin ve kişi hak ve özgürlüklerinin tam olarak yerleşmediği düzenler ise kendileri her türlü aykırı ifadeye karşı koruma altına almak zorunda hissetmektedir.

İç hukukumuza baktığımızda, 1982 Anayasası'nın 26. maddesi, "Düşünceyi Açıklama ve Yayma Hürriyetini” düzenlerken; 28. maddesi ise özel olarak "Basın Hürriyetini” düzenlemektedir. Söz konusu 28. maddede; "Basın hürdür, sansür edilemez. Basımevi kurmak izin alma ve malî teminat yatırma şartına bağlanamaz. Devlet, basın ve haber alma hürriyetlerini sağlayacak tedbirleri alır." denmekte ve "Basın hürriyetinin sınırlanmasında, Anayasa'nın 26. ve 27. maddeleri hükümleri uygulanır." denmek suretiyle, bu özgürlüğün kullanılmasının sınırlamaları olduğuna işaret edilmektedir. Bu sınırlamalar, düşünceyi açıklama ve yayma hürriyeti altında düzenlenmiş olup basın özgürlüğü ayrı bir düzenlemeye tabi tutulmamıştır.

Düşünceyi açıklama ve yayma hürriyetinin sınırlama nedenleri, 26. maddenin 2. fikrasında;

1. Millî güvenlik, kamu düzeni, kamu güvenliği,

2. Cumhuriyet'in temel nitelikleri ve devletin ülkesi ve milleti ile bölünmez bütünlüğünün korunmas1,

3. Suçların önlenmesi, suçluların cezalandırılması, devlet sırrı olarak usulünce belirtilmiş bilgilerin açıklanmaması,

4. Başkalarının şöhret veya haklarının, özel ve aile hayatlarının yahut kanunun öngördüğü meslek sırlarının korunması veya

5. Yargılama görevinin gereğine uygun olarak yerine getirilmesi olarak düzenlenmiştir.

AİHM, incelediği davalarda dava konusunun 10. maddenin ihlali olup olmadığ konusunda çok titiz davranmakta; davayı ve dava konusu sınırlama nedenini başlıca üç kritere göre değerlendirmeye tabi tutmaktadır. Söz konu kriterler;

- Sinırlama veya müdahalenin kanunla belirtilmiş olması:

Ceza hukukunda suç ve cezanın tanımı yapılmış olup herhangi bir olayın suç sayılabilmesi ve ceza müeyyidesi uygulanabilmesi için kanunla öngörülmüş olması gerekmektedir. AİHS'nin birçok maddesi de "yasayla öngörülen" veya "yasaya göre" gibi ifadelerle kanunilik ilkesine 
Şahin, Z.B. (2017). Avrupa İnsan Hakları Mahkemesi kararlarında basın özgürlüğünü sınırlama nedeni olarak genel ahlak. International Journal of Social Sciences and Education Research, 945-956.

gönderme yapmaktadır. (Baykan, 2011:73) Bu noktada kastedilen, 10. maddenin kapsamında yer alan özgürlüğe müdahalenin meşru bir temele ve iç hukukta yer alan bir kanuna dayanması gerektiğidir.

\section{- Sinirlamanin meşru ve haklı bir amaca dayanmast:}

Sözleşme'nin 10. maddesinin 2. fikrasında "meşru ve haklı" olarak kabul edilen amaçlar, genel bir biçimde sıralanmıştır. Dava konusu olayın bu maddeler kapsamında değerlendirilip değerlendirilemeyeceği ise Mahkeme tarafindan sıkı bir denetimle belirlenmektedir. Bu noktada dikkat edilmesi gereken en önemli husus, müdahaleye izin veren 2. fikra hükmünün istisna sıfatıyla dar yorumlanacağıdır. 10. maddenin 2. fikrasında yer alan sınırlamalar ise net bir biçimde ifade edilmiş olup hiçbir şekilde alt maddelere indirgenmemekte; bu nedenler dişında herhangi bir neden, ifade özgürlüğünü sınırlama hususunda meşru ve haklı bir amaç olarak kabul edilmemektedir.

- Sinırlamanin demokratik bir ortamda gerekli ve orantill olmast:

Demokratik toplum kriteri, gerek Medeni ve Siyasal Haklar Sözleşmesi'nde gerekse AİHS'de kendine yer bulmakta ve AİHS'nin en orijinal kriteri olarak kabul edilerek önsözünde yer almaktadır.

\section{Basın özgürlüğünün sınırlama nedeni olarak genel ahlak}

"Genel bir anlatımla ahlak; belirli bir dönemde belirli insan topluluklarınca benimsenmiş olan, bireylerin birbirleriyle ilişkilerini düzenleyen törel davranış kurallarının, yasalarının, ilkelerinin bütünü veya farklı toplumlarda ve zamanlarda kapsamı ve içeriği değişen ahlaki değerler alanıdır." (Kıllıŏlu'ndan aktaran Özgen, 2006:27) Bir diğer tanımla da ahlak; mutlak olarak iyi olduğu düşünülen ya da belli bir yaşam anlayışından kaynaklanan davranış kuralları bütünüdür. (Girgin, 2008:223)

Tanımlamalardan da anlaşılacağı üzere ahlakın en genel özellikleri "göreceli" ve "değişken" olmasıdır. Genel anlamda ahlak, iyiyi ve doğruyu hedefler. Bu her birey ve toplum için aynıdır. Ancak iyinin ve doğrunun ne olduğu, toplumdan topluma değişebileceği gibi, aynı toplum içindeki bireyler arasında da, zaman içinde de değişkenlik gösterebilir.

Ahlakın bu göreceli ve değişken yapısı, onu, ifade özgürlüğünü sınırlama nedeni olarak tehdit edici bir hale sokmaktadır. (Bulut, 2000:29) Nitekim kavramın somut ölçütlere dayanmaması, kanun koyucu ve iktidara söz konusu sınırlamalara ilişkin çok geniş bir takdir alanı bırakmaktadır. Buna göre iktidar; ahlaka aykırı bulduğu herhangi bir düşüncenin ifadesini keyfi olarak kısıtlama hakkına sahip olacaktır. Bununla birlikte, devletin ahlak alanına müdahalesi ve belirli bir ahlaki sistemi empoze etmesi günümüz demokrasi ve hukuk devleti anlayışıla kesinlikle bağdaşmamaktadır. (Bulut, 2000:34)

Gerek Avrupa İnsan Hakları Mahkemesi gerekse Amerikan Yüksek Mahkemesi, kavrama bir "somutluk" addetmek amacıyla, bu hususta düşünceyi açıklama özgürlüğüne ve basın özgürlüğüne getirilebilecek sınırlamalarda "müstehcenlik" kavramını esas almaktadır. (Salihpaşaoğlu, 2007:72)

Müstehcen kavramı, açık seçik, edebe aykırı ve yakışıksız olma anlamında kullanılmaktadır. (Çevrimiçi)

http://www.tdk.gov.tr/index.php?option=com_bts\&arama=kelime\&guid=TDK.GTS.5352cd73a 
Şahin, Z.B. (2017). Morality as the limitation of press freedom in the decisions of the European Court of Human Rights. International Journal of Social Sciences and Education Research, 945-956.

c4f76.02643180, 22.02.2013) Ancak neyin müstehcen kabul edilip neyin edilmeyeceği, uygulamada yine karışıklığa sebep olabilmektedir. Bütün toplumlar, müstehcen yayınlara belirli bir sınırlama getirmiştir. Değişen ise sınırlamanın nerede başladığı ve neyin müstehcen kabul edildiğidir. Schauer, "İfade Özgürlüğü, Felsefi Bir İnceleme" adlı eserinde müstehcenliğin denetlenmesini üç temel nedene bağlamıştır; (Schahuer, 2002:243-245)

İlk olarak müstehcen yayınlar ahlak dışıdır, toplumun kendi ahlâk standartlarının korunmasındaki çıkarı, egemen ahlâk değerlerine uymayan yayınların sınırlanmasına olanak sağlar; hatta buna zorlar.

İkincil olarak bu tür materyaller içeren yayınlar bazı toplum dışı davranışlara sebep olur, bu tür yayınlarla suç arasında bir nedensellik bağı vardır, bu tür materyaller içeren yayınlar toplumu çirkinleştirir ve kentsel çürümeye yol açar.

Ve son olarak insanlar müstehcen materyallere bakmak zorunda birakılarak rahatsız edilmektedir. Bu nedenle müstehcenliğin umuma açık bir şekilde sergilenmesi sınırlanmalıdır.

Schauer'in sıraladığı nedenler arasında bizce konumuzla en ilgili olan müstehcen materyallerin toplum düzenini bozabileceği ve toplum dışı davranışlara sebep olacağ 1 görüşüdür. Nitekim devletlerin bireylerin ahlak anlayışına karışması, ne günümüz demokrasi anlayışıyla ne de kişi hak ve özgürlükleriyle bağdaşmamaktadır. Devleti ilgilendiren kişinin ahlak anlayışının kamu düzeninde yarattığı ve/veya yaratacağı zarardır.

Amerikan Yüksek Mahkemesi, Miller v. California kararında bir yapıtın müstehcen olarak nitelendirilebilmesi için üç temel kriter sunmuştur. Bunlar; (Salihpaşaoğlu, 2007:73)

- Yapıtın yoğun biçimde şehvet arzusunu kışkırtması,

- Çok açık bir biçimde açık ve nahoş olması,

- Hiçbir sosyal değere sahip olmayan bir malzeme içermesidir.

Mahkeme, 2002 yılında verdiği bir kararla da bu durumu açıklamıştır. Kararda, kırktan fazla filme konu olan William Shakespeare'in "Romeo ve Juliet" isimli eserinin ve bu eserin ilham kaynağı olduğu filmlerin bazılarının ve en iyi film Oscar ödülünü kazanan "Amerikan Beauty" filminin de benzer ögeler içerdiğini; bu eserlerin, değerine bakılmaksızın müstehcen olarak nitelendirilmesinin Anayasa'ya aykırı olacağı belirtilmiştir. (Ashcroft v. Free Speech Coalition, 535 U.S. 234, 2002. Aktaran Salihpaşaoğlu, 2007:74)

AİHM kararlarına baktığımızda ise Mahkeme'nin, genel ahlak kavramının bu göreceli ve değişken yapısını göz önünde bulundurarak, devlet yetkililerine geniş bir takdir alanı bıraktığ görülmektedir. AİHM, bu hususta belirli kıstaslar belirlemekten kaçınmakta ve bu konudaki kararlarda, davalı devletlere, nispeten daha geniş bir takdir alanı tanımaktadır. Mahkeme'nin genel ahlaka ilişkin sınırlamaları konu alan ilk dava olan Handyside davasında verdiği karar, bu tutumunu açıkça sergilemektedir. (Handyside v. UK, 07.12.1976, 5493/72)

Söz konusu davada, iki Danimarkalı yazarın okullar için yazdığı ve cinsel ilişki, mastürbasyon, orgazm, kürtaj, homoseksüellik gibi cinsel içerikli bilgiler içeren Küçük Kırmızı Ders Kitabı isimli kitap, müstehcen içeriğe sahip olduğu iddiasıyla toplatılarak imha edilmiş ve yayınc1sına para cezası verilmiştir. Yayıncı Richard Handyside'ın başvurusu üzerine davayı inceleyen AİHM ise davacının aleyhine karar vererek müdahalenin genel ahlakın korunması için demokratik bir toplumda gerekli olduğuna karar vermiştir. Mahkeme, bu kararını şöyle açıklamaktadır; 
Şahin, Z.B. (2017). Avrupa İnsan Hakları Mahkemesi kararlarında basın özgürlüğünü sınırlama nedeni olarak genel ahlak. International Journal of Social Sciences and Education Research, 945-956.

"Sözleşmeci devletlerin değişen iç hukuklarında tek biçimli bir Avrupa ahlak kavramı bulmak mümkün değildir. Hukukun ahlaki değerlere yaklaşımı zamana ve yere göre değişmektedir. Dolayısıyla devlet yetkilileri ülkelerinin esaslı güçleriyle doğrudan ve sürekli ilişkide bulunmaları nedeniyle, ahlaki gereklerin içeriklerini ve bunları karşılamak için tasarladıkları yasak ve cezaların gerekliliği hakkında bir görüş bildirirken, genellikle uluslararası bir yargıçtan daha iyi konumdadırlar.” (Handyside v. UK, 07.12.1976, 5493/72, par.48. Kararın bu bölümünde yap1lan alıntı için bkz Baykan, 2011:81)

Kararın en ilginç kısmı ise, kitabın Avrupa Konseyi’ne üye birçok ülkede serbestçe yayınlanabilmesine karşılık, İngiltere'de yasaklanmış olmasıdır. (Cankaya, Yamaner, 2006:30) Mahkeme, bunu farklı Avrupa ülkelerinin iç hukuklarından ortak bir ahlak anlayışı çıkarmanın mümkün olmamasıyla bağdaştırmaktadır. (Handyside, 07.12.1976, 5493/72, par.48)

Mahkeme'nin ifade özgürlügünün sınırlama nedeni olarak genel ahlaka ilişkin verdiği bir diğer önemli karar ise Müller kararıdır. (Müller v. Swiss, 24.05.1988 10737/84) Dava, İsviçre'de bir modern sanatlar galerisinde sergilenen bazı tabloların müstehcen bulunarak İsviçre Ceza Kanunu'nun müstehcen eserleri yasaklayan 204. maddesi uyarınca söz konusu tablolara el konması ve ilgililerin para cezasına çarptırılması üzerine açılmıştır. (Cankaya, Yamaner, 2006:31)

Dava, Mahkeme'nin 10. maddenin ihlal edilmediğine yönelik karar vermesiyle, başvurucu Müller aleyhinde sonuçlanmıştır. Bununla birlikte, AİHM'nin sanat özgürlüğünün de 10. madde kapsamında değerlendirilebileceği görüşünü karara bağlaması açısından ayrı bir önem taşımaktadır. Ancak bu hususta AİHM'nin Amerikan Yüksek Mahkemesi'nin kriterlerini dikkate almadığını belirtmekte fayda görülmektedir. Nitekim söz konusu davada, müstehcenlik iddiası taşıyan eşcinsellik, hayvanlarla cinsel ilişki, mastürbasyon ve livata sahnelerini içeren dava konusu tabloların birer sanat eseri olmasına bakılmamış; eserin sosyal bir mesaj ya da sanatsal bir değer taşımasından ziyade etrafa verebileceği rahatsızlık üzerinde durulmuştur. Oysa bilim ve sanat özgürlüğü, bizce ifade özgürlüğünün kullanılmasındaki en değerli araçlardır. Kanun koyucunun ve yargı organlarının bu özgürlüklerin kısıtlanmasına en yüksek düzeyde hassasiyetle yaklaşmaları toplumun gelişmesi önünde bu alanlarda oluşabilecek engelleri en aza indirgeyecektir. (Cankaya, Yamaner, 2006:31)

Mahkeme'nin genel ahlakın korunmasına ilişkin verdiği bir diğer karar ise başvurucu lehine sonuçlanan Open Door and Dublin Well Woman kararıdır. Mahkeme, bu davada daha evvel yerel otoritelere tanınması gerektiğini belirttiği takdir hakkının kayıtsız, şartsız ve denetlenemeyecek bir hak olmadığını belirtmiştir. (Open Door and Dublin Well Woman v. İreland, 29.10.1992, 14234/88-14235/88, A 246-A Aktaran Salihpaşaoğlu, 2007:75)

Genel ahlaka aykırılık, iç hukukumuzda ise Anayasa'nın 26. maddesinin 3. fikrasında ifade özgürlügünü sınırlama nedeni olarak belirtilmiş; müstehcenlik kavramı ise 5237 sayılı Türk Ceza Kanunu'nun 226. maddesinde bir suç olarak düzenlenmiştir. Söz konusu maddenin 2. fikrasında; "Müstehcen görüntü, yazı veya sözleri basın ve yayın yolu ile yayınlayan veya yayınlanmasına aracılık eden kişi altı aydan üç yıla kadar hapis ve beş bin güne kadar adlî para cezası ile cezalandırılır." denmektedir. Aynı maddenin 7. fikrası ise; "Bu madde hükümleri, bilimsel eserlerle; üçüncü fikra hariç olmak ve çocuklara ulaşması engellenmek koşuluyla, sanatsal ve edebi değeri olan eserler hakkında uygulanmaz." ifadeleri ile Amerikan Yüksek Mahkemesinin müstehcenlik kriterlerine paralel bir tutum sergilemektedir. 
Şahin, Z.B. (2017). Morality as the limitation of press freedom in the decisions of the European Court of Human Rights. International Journal of Social Sciences and Education Research, 945-956.

Ülkemizde kanun maddeleri sıklıkla değiştirilmekte ve AİHS'ne uygun hale getirilmeye çalışılmaktadır. Ancak bu çabaların tutuklu gazeteci sayısında önemli ölçüde bir iyileşme göstermediği açıktır. Bu noktada sorun, kanun maddelerinden ziyade söz konusu maddelerin algılanma ve uygulanma biçiminden kaynaklanmaktadır. Mahkeme'nin Tyrer davasındaki şu sözleri gayet anlamlıdır;

“Sözleşme, bugünkü koşullar altında yorumlanması gereken... yaşayan bir belgedir.”

Mahkeme, yıllar itibariyle basın özgürlüğünü sınırlama alanını oldukça daraltmış ve davaları incelemek adına birçok kriter geliştirmiştir. Türkiye'de de ifade özgürlüğünün sınırlanmasına yönelik kanun maddelerinin geniş yorumlanmasından vazgeçilmeli; bu hususta çeşitli kriterler geliştirilerek sınırlandırmalar her olay kendi içinde değerlendirilerek daha hassas ve özgün bir biçimde ele alınmalıdır. Aksi takdirde kanunlarda yapılan değişiklikler uygulamada kendine yer bulamamakta; AB'ne uyum çerçevesinde gerçekleştirilen yeni düzenlemeler ise kâğıt üstünde kalmaya mahkûm olmaktadır.

\section{Sonuç}

Avrupa İnsan Hakları Mahkemesi (AİHM), 1959 yılında, uluslararası bir teşkilat olan Avrupa Konseyi'ne bağlı olarak kurulmuş uluslararası bir mahkemedir. Mahkeme, Avrupa İnsan Hakları Sözleşmesi ve ek protokolleriyle güvence altına alınmış olan temel hakların çiğnenmesi durumunda bireylerin, birey gruplarının, tüzel kişiliklerin ve diğer devletlerin, belirli usul kurallar dâhilinde başvurabileceği bir yarg1 merciidir. Türkiye de Avrupa Konseyi üyesi diğer 46 ülke ile birlikte AİHM'nin yetkisini tanımaktadır. Bununla birlikte 2004 yılında Anayasa'nın 90. maddesinde yapılan değişiklikle, temel hak ve özgürlükleri içeren başlıklar söz konusu olduğunda kanunların aynı konuda farklı hükümler içermesi durumunda uluslararası anlaşma hükümlerinin esas alınacağı da hükme bağlanmıştır.

Günümüzde basın özgürlüğünün sınırları hususunda birçok Anayasa'nın AİHS'nin 10. maddesinde sıralanan sınırlamaları benimsediği görülmektedir.

Sözleşme'nin 10. maddesinde; "Herkes görüşlerini açıklama ve anlatım özgürlüğüne sahiptir. Bu hak, kanaat özgürlüğ̈nü, kamu otoritelerinin müdahalesi ve ülke sınırları söz konusu olmaksızın haber veya fikir alma ve verme özgürlüğünü de içerir. Bu madde, devletlerin radyo, televizyon ve sinema işletmelerini bir izin rejimine bağlı tutmalarına engel değildir." denmektedir. Maddenin devamında ise bu özgürlüklerin kullanılması görev ve sorumluluklar yükleyen özgürlükler olduğu belirtilmiş ve kanunla öngörülen bazı formalitelere, şartlara, sınırlamalara ve yaptırımlara bağlanılabileceği belirtilmiştir.

Günümüzde basın özgürlüğünü de kapsayan ifade özgürlüğüne ilişkin kısıtlamaların özellikle gelişmiş Batı ülkelerinde mümkün olduğunca daraltıldığı görülmektedir. Mahkeme bu hususta sözleşmenin yaşayan bir varlık olduğu görüşünü savunmakta ve kararlarını bizzat sözleşemenin de üstünde konumlandırmaktadır.

Değişken ve göreceli yapısıyla ahlak, ifade özgürlügünün meşru sınırlama nedeni olarak tartşmalı bir zeminde yer almaktadır. Nitekim zamana ve mekana dayanıklı evrensel bir ahlak anlayışı yoktur. Bununla birlikte bazı evrensel değerlerin korunması ve ifade özgürlüğünün sınırlarının bunlara gore belirlenmesi ifade özgürlüğü de dahil olmak üzere temel kişi hak ve özgürlüklerinin korunması açısından önem arz etmektedir. 
Şahin, Z.B. (2017). Avrupa İnsan Hakları Mahkemesi kararlarında basın özgürlüğünü sınırlama nedeni olarak genel ahlak. International Journal of Social Sciences and Education Research, 945-956.

Mahkeme bu husuta ahlakın göreceli yapısını göz önünde bulundurarak sözleşmeci devletlere diger sınırlama nedenlerine nispeten daha geniş bir takdir marjı bırakmaktadır. Bunun temel nedeni ise yerel otoritelerin halkı uluslararası bir yargı organından daha iyi analiz edebileceği savıdır. Ancak göreceli ve değişken yapısı ahlakı bir basın özgürlüğü sınırlama nedeni olarak tehdit edici bir konuma sokmakta; yerel iktidarlarca gerçekleştirilebilecek keyfi uygulamalara izin verebilmektedir. Bu nedenle konunun mümkün olduğunca somutlaştırılması ve söz konusu davaların belirli kriterler çerçevesinde değerlendirilmesi gerekmektedir. Nitekim Amerikan Yüksek Mahkemesi'nin bu hususta belirlediği kriterler oldukça müstehcenlik kavramını esas alarak konuyu somutlaştırmakta ve sınırları nispeten net çizgilerle ortaya koymaktadır. 5237 Sayılı Türk Ceza Kanunu'nun 7. Maddesinin de söz konusu kriterleri esas aldığı görülmektedir. Ancak günümüzde kanunlardan ziyade kanunların uygulanma biçimi önem kazanmaktadır. Nitekim gerek Amerikan Yüksek Mahkemesi gerekse AİHM, yıllar itibariyle basın özgürlügünü sınırlama alanını oldukça daraltmış ve davaları incelemek adına birçok kriter geliştirmiştir. Türkiye'de de ifade özgürlüğünün sınırlanmasına yönelik kanun maddelerinin geniş yorumlanmasından vazgeçilmeli; bu hususta çeşitli kriterler geliştirilerek sınırlandırmalar her olay kendi içinde değerlendirilerek daha hassas ve özgün bir biçimde ele alınmalıdır. Aksi takdirde kanunlarda yapılan değişiklikler uygulamada kendine yer bulamamakta; AB'ne uyum çerçevesinde gerçekleştirilen yeni düzenlemeler ise kâğı̆t üstünde kalmaya mahkûm olmaktadır.

\section{Kaynakça}

Araslı, Oya (1995). “Anayasa Hukuku Açısından Düşünce Özgürlüğü”, Düşünceye Saygl, Düşünce Özgürlüğ̈̈ Konuşmalarl, Edebiyatçılar Derneği, Ankara, s.19

Baykan, Metin (2011.) Avrupa İnsan Hakları Mahkemesi Kararlarında Basın Özgürlüğü, Adalet Yay1nevi, Ankara.

Bıçak, Vahit (2001). “Avrupa İnsan Hakları Mahkemesi Kararları Işı̆̆ında İfade Özgürlüğü”, Liberal Düşünce, Y11:6, Say1:24, Güz, s.55-77.

Bulut, Nihat (2000). "Hak ve Özgürlüklerin Sınırlandırma Nedeni Olarak Genel Ahlak”, AÜEHFD, Cilt IV, Sayı:1-2, s.29-42.

Cankaya, Özden; Yamaner, Melike Batur (2006). Kitle İletişim Özgürlüğ̈̈, Turhan Kitabevi, Ankara.

Girgin, Atilla (2008). Gazeteciliğin Temel İlkeleri, Der Yayınları, İstanbul.

Odyakmaz, Necla (2003). “Basın Özgürlüğünün Düşünsel Tarihi” İ. Ü. İletişsim Fakültesi Dergisi, Say1:18, s.141

Özgen, Murat (2006). Gazetecinin Etik Kimliği, Set-Systems, 3. Bask1, İstanbul.

Salihpaşaoğlu, Yaşar (2007). “Türkiye'de Basın Özgürlüğü”, Yayımlanmamış Doktora Tezi, Ankara Üniversitesi Sosyal Bilimler Enstitüsü Kamu Hukuku Anabilim Dalı, Ankara

Schauer, Frederick (2002). IIfade Özgürlüğü: Felsefi Bir İnceleme, Çev. M. Bahattin Seçilmişoğlu, Liberal Düşünce Topluluğu, Ankara.

(Çevrimiçi) http://www.tdk.gov.tr/index.php?option=com_gts\&arama=gts\&guid=TDK.GTS.5352cb1639c897.183 $73597,01.01 .2013$

(Çevrimiçi) http://www.tdk.gov.tr/index.php?option=com_bilimsanat\&arama=kelime\&guid=TDK.GTS.5352cbbc 34bb19.04453211, 24.12.2013

(Çevrimiçi) http://www.tdk.gov.tr/index.php?option=com_bts\&arama=kelime\&guid=TDK.GTS.5352cd73ac4f76. $02643180,22.02 .2013$ 
Şahin, Z.B. (2017). Morality as the limitation of press freedom in the decisions of the European Court of Human Rights. International Journal of Social Sciences and Education Research, 945-956.

\section{Extended abstract in English}

Press, one of the most effective use tool of the freedom for expression, has an unarguable importance because of its place in pluralistic democratic regime as fourth force. As press takes its legality from this view which sees itself as a part of democratic regime, similarly the government ensures and certify its legality and security with the media's supervision power. Freedom of press consists of rights and freedoms which can be summerized as printing, publishing and distributing news, thoughts, comments and analysis and critics freely. This right that can be used within responsibilities is limited by certain reasons as all other freedoms. Although these limits range in different communities, the verdicts of European Court of Human Rigts show the increasingly tend to restrict the scope of the article in democratic countries.

The perception of individual rights and freedoms in a society goes parallel to the democracy's assimilation phase of the country. It may be considered normal for democracy to protect itself up to a point. But after that point democracy will expand to the extent that it will allow contrary views to itself. The ECHR, which is an international jurisdiction in the field, leaves a relatively broad margin of appreciation to contracting states, particularly in matters shaped by the heritage, cultural traditions and customs of societies, such as general morality and religious values, and adapts to the decisions of local authorities. However, this margin of appreciation is also not limitless given the increasing importance of freedom of the press, which is becoming increasingly isolated in the globalizing and commercializing world. As a matter of fact, the Court has developed various criteria for general morality as well as for the reasons of other legitimate restrictions and subject the case to a detailed assessment of the criteria.

Ethics, both variable and relative, are located on a controversial ground for the legitimate limitation of freedom of expression. As a matter of fact, there is no sense of universal morality that is resistant to time and space. However, protection of some universal values and gender identification of the boundaries of freedom of expression are important for the protection of fundamental human rights and freedoms, including freedom of expression. Considering the relative structure of this moral code, the Court leaves a relatively wider margin of appreciation for contracting states to the other reasons for restraint. The main reason for this is the argument that local authorities can better analyze the public from an international judiciary.

However, the relative and variable structure puts morality in a threatening position as a limitation of press freedom; May allow arbitrary applications to be carried out by local authorities. For this reason, it is necessary that the subject be embodied as much as possible and such cases should be evaluated within the framework of certain criteria. As a matter of fact, the criteria set by the Supreme Court of the United States embody the concept based on the concept of obscenity and shows the boundaries with relatively clear lines. The American Supreme Court, Miller v. California has made three basic criteria for a work to be considered obscene;

The intense provocation of desire for lust, to be clearly open and unpleasant, to contain a material that does not have any social value. In our country, the law is frequently amended and efforts are made to bring the ECHR into conformity. However, it is clear that these efforts did not show a significant improvement in the number of arrested journalists. At this 
Şahin, Z.B. (2017). Avrupa İnsan Hakları Mahkemesi kararlarında basın özgürlüğünü sınırlama nedeni olarak genel ahlak. International Journal of Social Sciences and Education Research, 945-956.

point, the problem arises from the way in which the subject matter is largely perceived and practiced. The following statement in the Tyrer case of the court is very meaningful;"The contract is a living document ... which has to be interpreted under present circumstances."

Over the years, the Court has narrowed the scope of restricting freedom of the press considerably and has developed many criteria for investigating the victims. In Turkey too, the broad interpretation of the law on the restriction of freedom of expression should be abandoned; By developing various criteria on this subject, the limitations should be considered in a more sensitive and original way by evaluating each event within itself. Otherwise, the changes made in the law will not find its place in practice and new arrangements in the EU harmonization will be condemned to stay on paper. 